INTERNATIONAL JOURNAL OF RESEARCHES IN BIOSCIENCES, AGRICULTURE AND TECHNOLOGY (c) VISHWASHANTI MULTIPURPOSE SOCIETY (G lobal Peace Multipurpose Society) R. No. MH-659/13 (N) www.vmsindia.org

\title{
ISOLATION OF MACROPHOMINA PHASEOLINA PATHOGEN FROM INFECTED PARTS OF SORGHUM STEMS
}

\author{
T. Srinivas ${ }^{1}$, S. Indira ${ }^{2}$ and Bhadraiah ${ }^{3}$ \\ 1Dept. of Botany, SRR Govt. Arts \& Science College Karimnagar. \\ ${ }^{2}$ Retired Senior Scientist, NRCS Rajendra nagar, Hyderabad \\ ${ }^{3}$ De pt. of Botany Os mania University, Hyderabad. \\ drstirukovela@gmail.com
}

\begin{abstract}
The pathogen M.phaseolina was successfully isolated from the basal portion of the charcoal rot of infected Sorghum stem collected from the fields of National Research Centre for Sorghum (NRCS) Rajendranagar, Hydersbad. In this present study small bits of sclerotia bearing strands we re surface sterilize d by imme rsing in 0.1 percent mercury chloride for two minutes. The surface sterilized strands washed in three changes of sterile distilled water. They we re planted on PDA under ase ptic conditions and incubated at 25C in SEW,BOD incubator. After 4days of incubation the fungus was transferred on a fresh PDA plate and was purified through single scle rotia isolation purified culture of M.phaseolina was maintained on PDA slants at room temperature(26-28C)..

Keywords: Sclerotia, aseptic and Charcoal rot
\end{abstract}

\section{Introduction}

Sorghum bicolor (L.) is an important crop for human consumption and animal fodder. It is grown principally for grain in the tropical and subtropical areas of the Indian sub continent. Sorghum attains the fourth place in India among the staple food crops. Sorghum crop suffers from many diseases and are caused by various organisms like bacteria, viruses, mycoplasma and fungal pathogens. Among fungal diseases during post rainy season charcoal rot is one of the important disease caused by Macrophomina phaseolina (Tassi) Goid. It is commonly referred as charcoal rot, due to presence of soot black sclerotia of M.phaseolina in lodged plants which cause severe yield loss.

\section{Materials and Methods}

The general laboratory techniques followed in this investigation were those as followed by Booth (1971) and Hawks worth (1974). A plot of $20 \times 30$ sq.ft was maintained at the fields of National Research Center for Sorghum (NRCS), Raje ndranagar, Hyderabad.

The pathogen M.phaseolina was successfully isolated from the basal portion of the charcoal rot of infected Sorghum stem collected from the fields of National Research Centre for Sorghum (NRCS) Raje ndranagar, Hyde rabad. In this present study small bits of sclerotia bearing strands we re surface sterilized by immersing in 0.1 percent mercury chloride for two minutes. The surface ste rilized strands washed in three changes of sterile distilled water. They were planted on PDA under aseptic conditions and incubated at 25C in SEW, BOD incubator. After 4days of incubation the fungus was transferred on a fresh PDA plate and was purified through single scle rotia isolation purified culture of M.phaseolina was maintained on PDA slants at room tempe rature $\left(26-28^{\circ} \mathrm{C}\right)$..

Maintenance of the Fungus:

Purified culture of M.phaseolina was maintained on PDA slants at room temperature $\left(26-28^{\circ} \mathrm{C}\right)$

\section{Cultural studies:}

The cultural characteristics viz, colony characters, morphology, mycelial growth and sclerotia production of $M$. phaseolina were studied on different culture media viz, potato dextrose agar, maize meal agar, oat meal agar and sorghum meal agar used. Autoclaved and cooled (40C) media were poured into sterilized glass petriplates and allowed to solidify, upon solidification of the meadia; plates were inoculated aseptically with $5 \mathrm{~mm}$ culture disc obtained from5-6 days old culture of M.phaseolina. Each treatment was replicated thrice and plates were incubated at room temperature.

Observations on radial mycelialgrowth, scle rotial production and cultural characteristics were recorded and presented in the table

\section{Results and Discussion}

Isolation of Macrophomina phaseolina pathogen:

M.phaseolina is a root-inhabiting fungus (Garrett, 1956) with little or no saprophytic growth in either soil or dead host cells of infected plants (Edmunds, 1964).In absence of host plants, it survives or over seasons predominantly as small black sclerotia root and stem debris or in soil after decay of the 
plant material in which they are formed ..(Smith, 1969, Bhattacharya and Sammaddar, 1976).Thus the primary source of inoculum is sclerotia in the soil. (Cook et al., 1973).Meyer et al., 1973 reported that after 16 months in soil,23\% of sclerotia from stalks have ge rminated. Populations of sclerotia in a maize field ranged from zero to 100 grams of soil (Papavizas and Klag, 1975).This variation in inoculum density in soil is one of the factor responsible for highly variable incidence of charcoal rot in th field..

The isolation of M.phaseolina from the surface sterilized sections illustrates that this fungus penetrated, some of the se dead tissue in the presence of other competitive and antagonistic soil microorganisms. There are only few reports on the quantitative isolation of M.phaseolina from soil as well as from diseased plants.

In the present study, the pathogen M.phaseolina was isolated from basal portion of the charcoal rot affected sorghum stems. The fungus culture maintained on PDA slants at room temperature. The isolation method involved in above study was reported earlier by Cook et al., (1973)., Meyer et al.,(1973)., Papavizas and Klag,(1975) and Dhingra and Sinclair,(1973).

\section{Culture Characteristics:}

Effect of different media on the growth of the M.phaseolina, Watanabe et al.,(1970)developed a differential flotation technique for assaying populations of M.phaseolina sclerotia in pine nursery soils. Meyer et al.,(!973) described two selective media with rice agar, the basal medium to isolate M.phaseolina from soil. Papavizas and Klag,(1975) reported the selective media and a method was developed for the direct isolation of M.phaseolina from soil. The similar reports are observed with reference to ergot pathogen Claviceps sorghi by Kumar and Arya,(1978). M.phaseolina survives in debris and soil as very small black sclerotia. The soil borne sclerotia caused greater disease incidence than mycelium. Selective media are needed to accurately assay all of the propgules of plant pathogens since saprophytic fungi are omini present in soil quickly over grow on agar plate s and prevent recovery of important pathogens. There are only few reports on the quantitative isolation of M.phaseolina from soil as well as from plant de bris.

In the present study, PDA was used as common medium for the growth and maintenance of the fungus. The affect of different media i.e. potato dextrose agar, oat meal agar, sorghum meal agar and maize meal agar was studied. The results are presented in the table no. 1

From the results obtained, it is clear that potato dextrose agar supported highest rate of growth of the fungus and least growth was observed in maize meal agar medium. There was no significant difference in the growth rate of fungus on oat meal agar and sorghum meal agar medium.

Table: 1 Radial growth of (mm/day) M.phaseolina on diffe re nt solid media

\begin{tabular}{|l|l|l|}
\hline $\begin{array}{l}\text { S. } \\
\text { No. }\end{array}$ & Media & $\begin{array}{l}\text { Radial } \\
\text { Growth(mm) }\end{array}$ \\
\hline 1 & Potato dextrose & 6.96 \\
& agar & \\
\hline 2 & Oat meal agar & 5.30 \\
3 & Sorghum meal & 4.23 \\
& agar & \\
\hline 4 & Maize meal agar & 2.96 \\
\hline
\end{tabular}

\section{Conclusion}

The charcoal rot fungus was isolated in pure culture from basal portion of the diseased stems and studied for various aspects as the re is little information avaliable in the literature. The growth of the M.phaseolina was studied in the meal obtained from sorghum and maize grains in addition to a non-host plants namely oats. PDA which is mostly used for the growth and maintenance of the fungus was used as a standard to compare the pathogen behaviour in the meals of grains of maize, sorghum and oat.

The growth rate of M.phaseolina per day was found to be maximum in $\operatorname{PDA}(6.96 \mathrm{~mm})$, next best growth was found in oat meal agar $(5.30 \mathrm{~mm})$, least growth was observed in sorghum meal agar $(4.3 \mathrm{~mm})$ and maize meal agar $(2.96 \mathrm{~mm})$. The increased growth in PDA could be attributed to 1 . The rich nutrients of potato extracts and 2 . The presence of essential carbon compounds namely glucose.

Oat meal agar is widely used medium next to PDA medium for the cultivation and maintenance of many fungii especially Pythium spp and Colletotrichum spp. This could to due to the availlability of adequate nutrients for the growth of fungii. But not to the extent available in PDA. Cereal meal media like maize and sorghum did not encourage the growth of the pathogen, which obviously projects the either lack of certain essential nutrients in the media or the presence of high carbohydrate contents in these meals which would have inhibited the growth of M.phaseolina. 


\section{References}

1. Aanahosur, K.H. and Patil, S.H.(1983). Assessment of losses in sorghum seed weight due to Charcoal rot. Ind.Phytopath 36(1):85-88.

2. Bainade, P.S et al.,(1978) - Growth of M.phaseolina on different media, $\mathrm{pH}$ and te mparature levels, J.P1.Dis .Sci 1 (1):70-73.

3. Bhattacharya, $M$ and K.R Sammaddar (1976). Epidemiological studies on iute, disease survival of M.phaseolina Ash by in soil. Plant soil : (44) : 27-36

4. Goyal, M.K and Mehrothra R.S (1982). Trace elements required for growth and sclerotional production of Rhizoctonia bataticola(M.phaseolina). J1. Ind. Bot. Sci., 61(10) : 47-60

5. Karunakar, R.I (1989), studies on root and stalk rot of sorghum with special reference to soil survival of stalk rot pathogens. Ph.D. Thesis, Osmania University, Hyderabad.

6. Meyer, W.A., J.B Sinclair and M.N khare (1973), Biology of M.phaseolina in soil studied with selective media. Phytopathology : 62 : 545-549

7. Mever, W.A., J.B Sinclair and M.N khare (1973), Biology of M.phaseolina in soil studied with selective media. Phytopathology : 63 : 613-620

8. Pande.S, Mughogho.L.K and Karunakar.R.I (1992), ICRISAT Incedence of charcoal rot in sorghum cultivars as affected by sowing date and plant density. Ind. $J$ plant prot. 20(2) : 162-170
9. Papavizas.G.C and Klag N.G (1975). Isolation and quantitative de te rmination of M.phaseolina from soil. Phyto Pathology. 65:182-187.

10. Parkinson.D and Thomas.A (1965), A comparison of methods of the isolation of fungi from rhizosphere. Can.J.Microbial 11: 1001-1007

11. Savvad.T.R.Mogle and S.A.Musmade (2013). Pathogenicity of M.phaseolina and cultural characteristics of the pathogen. Flora and Fauna. 19(1):192-196

12. Singh.S.K and Nene.Y.L (1990), cross inoculation studies on Rhizoctonia bataticola(M.phaseolina), isolates from different crops. Ind. Pyhto Path., 43(3) : $446-448$

13. Sobti.A.K and Bansal.R.K (1988), cultural variability among the isolates of Rhizoctonia bataticola(M.phaseolina) from ground nut. Ind. Phytp path 41(1): 149-151

14. Suriachandrselvan, $M$ and Seetharaman,K (2003), effect of media on growth and sclerotial production of different isolates of Rhizoctonia bataticola(M.phaseolina) infecting sunflower. J.Mycol.P1.Pathology., 33(2):22 6-229

15. Watanabe.T, R.S Smith,JR and W.C Snydeer (1970), population of M.phaseolina in soil affected by fumigation and cropping. Phyto pathology. 60:1717-1719 